\title{
Blue duiker Philantomba monticola densities in the Tsitsikamma National Park and probable factors limiting these populations
}

\section{N. HANEKOM and V. WILSON}

Hanekom, N. and V. Wilson. 1991. Blue duiker Philantomba monticola densities in the Tsitsikamma National Park and probable factors limiting these populations. Koedoe 34(2): 107-120. Pretoria. ISSN 0075-6458.

\begin{abstract}
Numbers of blue duikers recorded on 157 and 28 variable width transect counts, done over a two year period in the Tsitsikamma Coastal National Park (TCNP) and Tsitsikamma Forest National Park (TFNP) respectively, did not differ significantly $(P>0,10)$ with seasons (summer v. winter). Population density estimates from transects were similar to those from game drives $(0,18$ v. 0,19 duikers/ha (TCNP) and 0,13 v. 0,17 duikers/ha (TFNP); $P>0,10)$, higher than from faecal pellet counts $(P<0,10)$ and at least three times lower than estimates from the Kenneth Stainbank Nature Reserve and Umdoni Park in Natal. Factors contributing to the low population densities in the Tsitsikamma national parks were investigated. Twentyseven and seven percent of leopard (25) and caracal (12) scats respectively analyzed contained blue duiker remains, but predator numbers appear to be low. Forest characteristics were investigated, and results from this and other studies suggest that undergrowth cover does not markedly influence blue duiker densities in the southern Cape forests. Field and stomach analysis indicate that blue duikers feed primarily on freshly fallen leaves and fruit, and are selective foragers. In the Tsitsikamma national parks (TNPs) the frequency of occurrence of trees known to be palatable to duikers are low, while less than 45 percent of the dominant tree species fruit fully annually. This apparent scarcity of food, the low numbers of antelope species and individuals in these forests and results from duiker research in Zaire, suggest that habitat rather than predation is limiting duiker numbers in the Tsitsikamma national parks.
\end{abstract}

N. Hanekom. Tsitsikamma National Park, P.O. Storms River, 6308 Republic of South Africa; V. Wilson. Chipangali Wildlife Trust, P.O. Box 1057, Bulawayo, Zimbabwe.

\section{Introduction}

Blue duikers, Philantomba monticola (Thunberg, 1789), are rare in South Africa (Smithers 1986) and confined to forests and thickets, primarily in the coastal strip extending from the Umfolozi River system in Natal to George in the southern Cape (Smithers 1983; Wilson 1987). They are recorded from only two South African national parks, Zuurberg and Tsitsikamma, but are found in several nature reserves in Natal (Bourquin et al. 1971; Bowland 1990a) and unprotected areas throughout their distribution (Bowland pers. comm.).

In the southern Cape numbers of blue duikers apparently decreased in the late 1940s and early 1950 s and remained depressed throughout the 1950s and 1960s, but have subsequently increased in the Tsitsikamma Coastal National Park (TCNP) (Crawford \& Robinson 1984). This decrease in duiker numbers and the slow recovery of the populations were respectively attributed to an increased abundance of caracal (Felis caracal Schreber, 1776) in the forests during (the drought of) the late 1940s (Thesen in litt. 1952 in Skead 1980; Liversidge 1966) and subsequent hunting by dogs and poachers (Liversidge 1966; Crawford \& Robinson 1984). This study compares blue duiker densities in the Tsitsikamma Coastal and Forest National Parks (TNPs) with those from other regions (Von Gadow 1978; Koster \& Hart 1988; Bowland 1990a) and discusses the probable effect of predation and habitat on the populations of the southern Cape. It complements the work of Crawford (1984) and Bowland (1990a, 1990b) on blue duiker in the TCNP and Natal respectively and forms part of a Pan-African decade of duiker research (Wilson 1987).

\section{Study area}

The terrestrial section (ca. $70 \mathrm{~km} \times 0,8 \mathrm{~km}$ ) of the Tsitsikamma Coastal National Park 


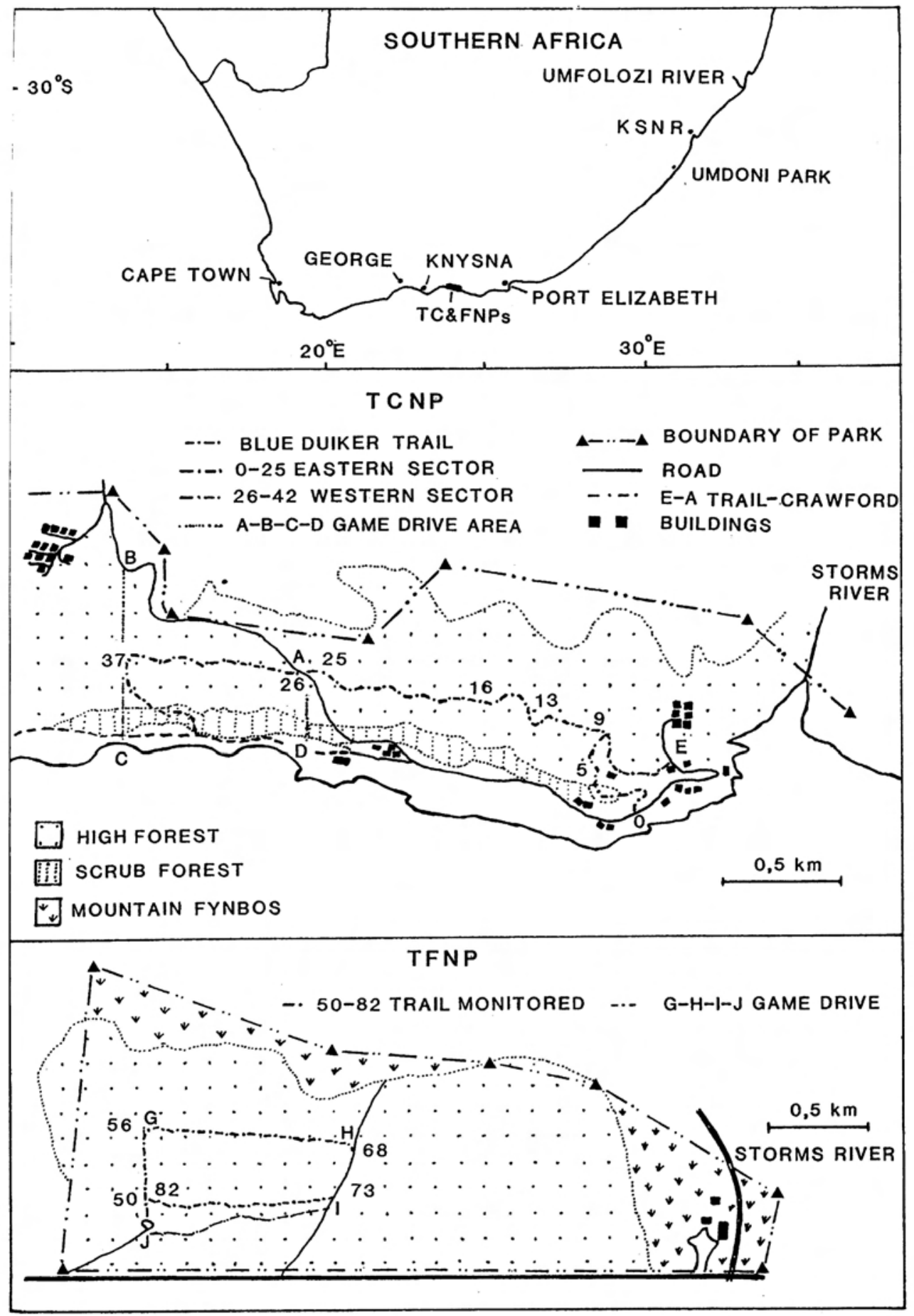

Fig. 1. Maps of : (A) southern Africa, (B \& C) the Storms River region of the Tsitsikamma Coastal National Park (TCNP) and the Tsitsikamma Forest National Park (TFNP) respectively, showing transect paths, game drive areas and trail used by Crawford (1984). KSNR = Kenneth Stainbank Nature Reserve. 


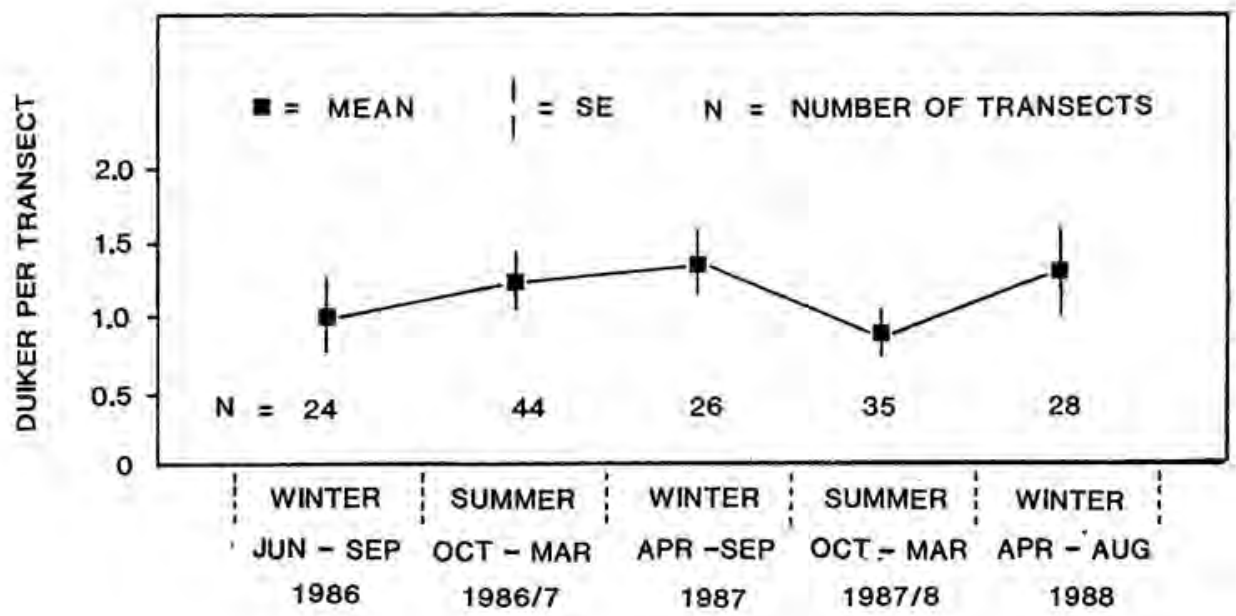

Fig. 2. Mean numbers of blue duikers seen per transects along the entire Blue Duiker Trail during winter (April September) and summer (October - March) periods between June 1986 to August 1988.

(TCNP) lies on a steeply sloping (0-180 m high) coastal escarpment, while the small (478 ha) Tsitsikamma Forest National Park (TFNP), which was deproclaimed and ceded to Department of Environment Affairs in 1989 , is on the lower slopes of the Tsitsikamma Mountain Range (ca. 240 - 550 $\mathrm{m}$ above sea level), some $7 \mathrm{~km}$ inland from Storms River Mouth (Figure 1). The climate in both areas is mild, with mean annual minimum and maximum temperatures approximating $8{ }^{\circ} \mathrm{C}$ and $24{ }^{\circ} \mathrm{C}$ respectively, while rainfall (1 000-1 $200 \mathrm{~mm})$ is evenly distributed throughout the year. The vegetation is mainly dry high (Afromontane) forest, dry scrub forest and mountain fynbos in the TCNP (Hanekom et al. 1989), and medium moist to moist Afromontane forest in the TFNP (Geldenhuys 1981). These forests are part of the southern Cape or Knysna (Afromontane) forest complex, a belt of isolated forest patches along the coastal plateau and lower slopes of the Outeniqua and Tsitsikamma mountains (Von Breitenbach 1974; Hanekom et al. 1989)

\section{Methods}

\section{Variable width transects:}

For census purposes blue duikers in the study area may be regarded as active throughout the day (Craw- ford 1984) and all counts in this study were done between 14:30 and 18:30. The 4,2-km Blue Duiker Trail, through forest and scrub forest in the TCNP (Figure 1B ), was walked approximately once a week between June 1986 and August $1988(n=157)$, while 28 transects were done along a $3,2 \mathrm{~km}$ path through forest in the TFNP (Figure IC). Blue duikers seen along the trails were recorded, and animal to transect path distances were determined for the last 54 and 15 sightings in the TCNP and TFNP respectively. Population densities were estimated applying the equation used by Bowland (1990a), namely:

$\mathrm{D}=\frac{Y}{2 L} W, \quad$ where

$\mathrm{D}=$ density per ha,

$\mathrm{Y}=$ total number of animals seen along transect path, $\mathrm{L}=$ length of transect path and

$\mathrm{W}=$ mean animal to sampling path distance (Collinson 1985).

\section{Drive counts:}

To determine the range of visibility within the forests and suitable spacing intervals between beaters on game drives, maximum distances at which a $(30 \mathrm{~cm} \mathrm{x}$ $40 \mathrm{~cm}$ ) brown sighting board was readily visible, were assessed in June 1988 and January 1989. Measurements were taken at $100 \mathrm{~m}$ intervals along the transect paths.

Three game "drives" were done in area A-B-C-D (in TCNP) and four in area G-H-1-J (in TFNP, Figure 1) between June and August 1988. Observers were spaced approximately $10 \mathrm{~m}$ apart and kept (as far as possible) abreast of each other as they moved quietly through the forest. Blue duikers in the study areas were accustomed to pedestrian traffic and could nor- 


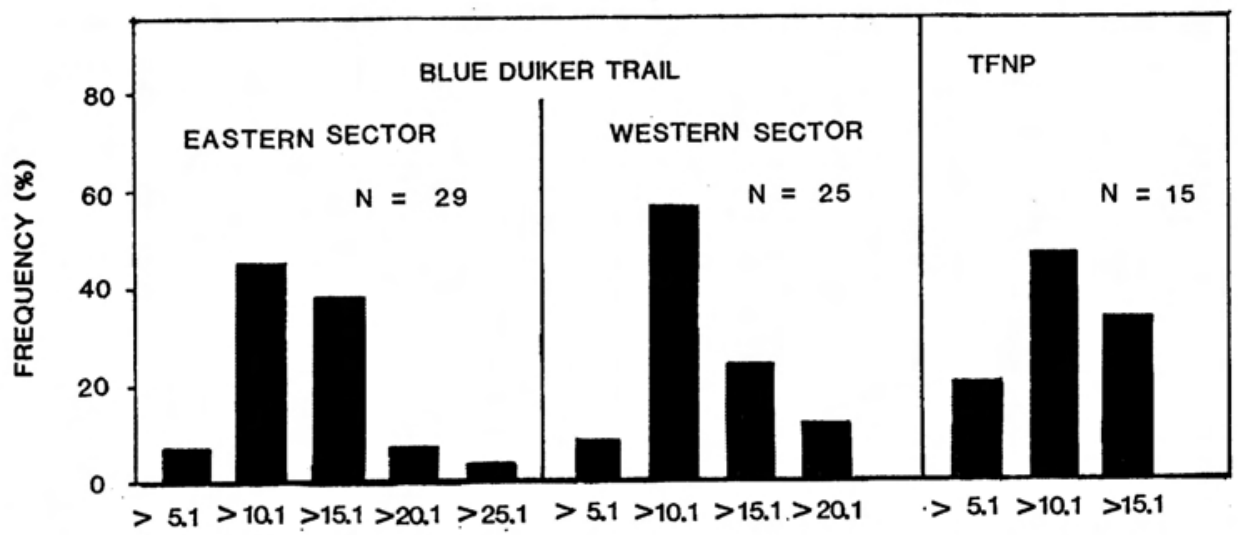

DISTANCE CLASS (m)

Fig. 3. Frequency distributions of animal-to- sampling path distances recorded along the Blue Duiker Trail and in the TFNP.

mally be approached to within 5-15 metres. This, together with the fact that they usually emit a shrill whistle when flushed (Crawford 1985), facilitated the counting process. Blue duikers are reluctant to leave their territories, they usually double back or hide on reaching territory boundaries (Bowland 1990b). Observers recorded numbers of duikers seen, the direction in which they moved and segment (north, middle or south) of the study areas where sightings were made. Two or three observers stationed on paths $\mathrm{C}$ $\mathrm{D}$ and $\mathrm{I}$ - $\mathrm{J}$ (Figure 1) recorded any animals fleeing the areas. Five and seven consecutive drives were needed to cover the study areas of the TCNP and TFNP respectively. By plotting the locality of each sighting and the direction in which the animals were moving, replicate records of the same individual were identified and the total number of duikers seen determined.

Both study sites lie length ways along steeply sloping escarpments and it was necessary to compensate for this when determining the area covered on each drive. Therefore, estimates of the vertical area (mean height $x$ mean breadth) of the study region were added to the (surface area) planimeter readings $\left(\mathrm{m}^{2}\right)$ from 1:10 000 orthophotographs.

\section{Faecal pellet counts:}

During these game drives the three most experienced beaters also recorded numbers of faecal pellet piles. It was assumed that: (i) the effective strip width for pellet counts was exactly $1,5 \mathrm{~m}$, (ii) faecal piles, which had not yet turned "mouldy" or started disintegrating were less than 25,5 days old (Von Gadow 1978) and (iii) the defecation rate of blue duikers was 2,5 piles per day (Von Gadow op cit.). Duiker densities were then calculated using the equation:
$\mathrm{D}=\frac{Y}{X} Z$, where:

$\mathrm{D}=$ densityper ha,

$\mathrm{Y}=$ number of faecal piles per ha,

$\mathrm{X}=$ defecation rate per $24 \mathrm{~h}$ and

$Z=$ Decay rate in days (Koster \& Hart 1988).

Blue duiker densities recorded from various southern Cape forests were compared with those of bushbuck, the other major antelope species in the above forests. To equate these values, bushbuck densities were multiplied by the ratio of the metabolic rate of bushbuck divided by that of blue duiker [adult masses $=35 \mathrm{~kg}$ and 4,2 kg respectively (Smithers 1983)], as determined by the mass $(\mathrm{M})$ metabolism (R) equation: $R$ $(\mathrm{kcal} / \mathrm{h})=\left(0,676 \mathrm{M}^{0,75}\right)$ (Schmidt-Nielsen 1985):

In March 1990 a fresh ( $c$. one hour old) road-kill was found about $0,5 \mathrm{~km}$ from the TCNP study site. The duiker carcass was measured and the abdominal organs removed. The liver was frozen and sent to the Regional Veterinary Laboratory in Stellenbosch for trace element analyses using atomic spectrometry. The stomach contents were washed in a $1,0 \mathrm{~mm}$ mesh sieve and sorted. Ingested items were compared with intact leaf and fruit specimens collected from the forest, and where possible items were identified to species level using herbarium samples and referring to Von Breitenbach (1974). The various fractions were then oven dried at $80^{\circ} \mathrm{C}$ for $48 \mathrm{~h}$, weighed to the nearest $0,01 \mathrm{~g}$ and expressed as a percentage of the total sample.

The duiker had apparently been feeding in the area, as freshly ingested food items were abundant in the forest bordering the road-kill site. Freshly fallen leaves and fruit were quantitatively collected from $100\left(0,25 \mathrm{~m}^{2}\right)$ quadrats randomly placed along the forest floor. Food items were identified, sorted and 
Table 1

Maximum distance at which sighting board was still readily visible in the forest $(\bar{x} \pm S E)$ and values for variable width transects, game drives and faecal pellet counts done in the Tsitsikamma national parks

\begin{tabular}{|c|c|c|c|}
\hline & TCNP & & TFNP \\
\hline \multicolumn{4}{|l|}{ Sighting- Board: } \\
\hline $\begin{array}{l}\text { Trail segments (Fig.1) } \\
\text { Max. dist. (winter) } \\
\text { Max. dist. (summer) }\end{array}$ & $\begin{array}{l}0-25 \\
6,2+0,5 \mathrm{~m} \\
6,0+0,5 \mathrm{~m}\end{array}$ & $\begin{array}{l}26-42 \\
6,6+0,5 \mathrm{~m} \\
6,4+0,6 \mathrm{~m}\end{array}$ & $\begin{array}{l}50-82 \\
6,8+0,3 \mathrm{~m} \\
-\quad \mathrm{m}\end{array}$ \\
\hline \multicolumn{4}{|l|}{ Line Transects: } \\
\hline $\begin{array}{l}\text { Trail segments } \\
\text { Length of trail (L) } \\
\text { Duiker/transect (Y) } \\
\text { Strip width (W) } \\
\text { Duiker/ha (Dx10000) }\end{array}$ & $\begin{array}{l}0-25 \\
2300 \mathrm{~m} \\
0,55+0,07 \\
12,3 \mathrm{~m} \\
0,10+0,01\end{array}$ & $\begin{array}{l}26-42 \\
1600 \mathrm{~m} \\
0,62+0,07 \\
10,9 \mathrm{~m} \\
0,18+0,02\end{array}$ & $\begin{array}{l}50-82 \\
3200 \mathrm{~m} \\
0,74+0,15 \\
8.6 \mathrm{~m} \\
0,13+0,02\end{array}$ \\
\hline \multicolumn{4}{|l|}{ Game Drives: } \\
\hline $\begin{array}{l}\text { Forest region (Fig. 1) } \\
\text { Area covered (ha) } \\
\text { Duiker/drive } \\
\text { Bushbuck/drive } \\
\text { Duiker/ha } \\
\text { Bushbuck/ha }\end{array}$ & $\begin{array}{l}\text { A-B-C-D } \\
- \\
- \\
- \\
- \\
-\end{array}$ & $\begin{array}{l}\text { G-H-I-J } \\
36,8 \\
7,00+0.58 \\
0,67+0,67 \\
0,19+0,01 \\
0,02+0,01\end{array}$ & $\begin{array}{l}42,0 \\
6,00+1,29 \\
1,25+0,63 \\
0,17+0,03 \\
0,03+0,01\end{array}$ \\
\hline \multicolumn{4}{|l|}{ Faecal Pellet Counts: } \\
\hline $\begin{array}{l}\text { Faecal pellets/ha (Y) } \\
\text { Defaecation / day }(\mathrm{X})^{89} \\
\text { Age of pellets (Z) } \\
\text { Duiker/ha (D) }\end{array}$ & $\begin{array}{l}- \\
- \\
-\end{array}$ & $\begin{array}{l}7,41+2,79 \\
2,5 \\
<25,5 \\
0,12+0,04\end{array}$ & $\begin{array}{l}4,49+0,73 \\
2,5 \text { piles } \\
<25,5 \text { days } \\
0,07+0,01\end{array}$ \\
\hline
\end{tabular}

${ }_{8}$ through forest
values derived from Von Gadow (1978).

treated as described above. These values were then compared with those from the stomach analysis.

The stem densities and dominant species in the shrub (1-2 m) and tree (>2,5 m) strata (Bowland 1990a) of the forests were determined along three equally spaced north-south transects through study sites A-BC-D and G-H-I-J (Figure 1), using the point-centre quarter method (Mueller-Dombois \& Ellenberg 1974). Measurements were taken at $20 \mathrm{~m}$ intervals along transect lines. Plants were identified using Von Breitenbach (1974) and the Saasveld herbarium, while stem diameter at breast height $(\mathrm{DBH})$ was determined for each tree.

Leopard and caracal scats, which are fairly large with a segmented appearance (Walker 1981), were collected whenever encountered in the TNPs or adjoining areas. There was no clear way of differentiating between the scats of small leopard and that of large caracal. Therefore, all scats having maximum diameter $>20 \mathrm{~mm}$ were regarded as leopard, while those $<20 \mathrm{~mm}$ as caracal (Norton et al. 1986). Scat samples were analyzed in the manner described by Grobler \&
Wilson (1972), with prey items being identified from fragments of hooves, nails, bones, teeth, hairs or feathers found in the faeces. The percentage occurrence and relative frequency of each prey item were determined.

\section{Results}

Maximum distances, at which the $30 \mathrm{~cm} \mathrm{x}$ $40 \mathrm{~cm}$ sighting board was readily visible in the forest bordering the Blue Duiker Trail, were similar in both summer and winter (paired $t$-test $=1,05 ; d f=77 ; P>0,10$, Table 1). Therefore, seasonal variations in visibility were unlikely to influence transect counts.

The mean numbers of blue duikers recorded per transect along the Blue Duiker Trail (segments 0 - 42) during the summer (October to March) and winter (April to September) periods between June 1986 and August 1988 
Table 2

Density estimates of blue duiker from Tsitsikamma (Table 1), Knysna (Von Gadow 1978), Zaire (Koster \& Hart 1988) and Natal (Bowland 1990a)

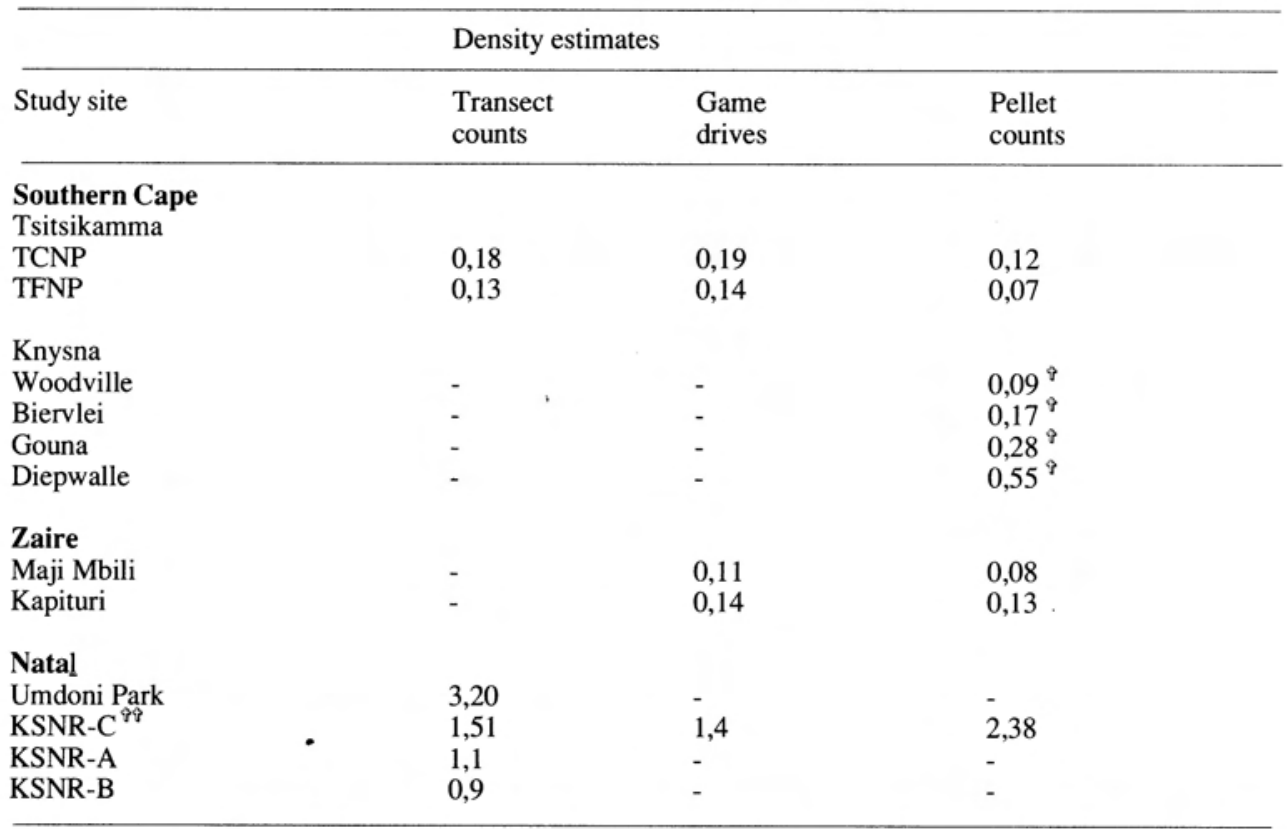

${ }^{8}$ Von Gadow's (1978) equation, which separated fresh from old faecal piles, is incorrect and density estimates were recalculated using the combined values for fresh ( 2 days) and old faeces ( $3-25,5$ days), assuming that these faecal groups were found in a ratio of 1: 11,75, as was recorded at Diepwalle (Von Gadow 1978).

${ }^{\curlyvee}$ KSNR = Kenneth Stainbank Nature Reserve - area C.

varied from 0,89 to 1,35 (Figure 2). However, these variations were not significant (anova $=0,81 ; d f=4 \& 152 ; P>0,10$, Snedecor 1965), and fluctuations were taken to be chance variations with no biological meanings.
Most blue duikers were sighted in open forest glades, their normal foraging areas (Bowland 1990a), and the animal-to-sampling line distances suggested duikers kept a "safe" distance $($ ca. $5 \mathrm{~m})$ from transect path used, especially the busy Blue Duiker Trail (Figure 3 ). This means that some animals may have

Table 3

Normal and metabolically standardized (relative to blue duiker) population density estimates for bushbuck and blue duiker in various southern Cape forests. Normal estimates for TNPs, Goudveld (bushbuck) and adjoining Gouna (bushbuck and duiker) Afromontane forests were taken from Table 1, Seydack (1983), Odendaal et al. (1980) and Von Gadow (1978 in Table 2) respectively, while the ratio of the metabolic rate of bushbuck to that of duiker $=4,9: 1$

\begin{tabular}{|c|c|c|c|c|}
\hline \multirow[t]{2}{*}{ Density } & (Goudveld) & Gouna & TFNP & TCNP \\
\hline & Bushbuck & $\begin{array}{l}\text { Bush- : Duiker } \\
\text { buck }\end{array}$ & $\begin{array}{l}\text { Bush- : Duiker } \\
\text { buck }\end{array}$ & $\begin{array}{l}\text { Bush- : Duiker } \\
\text { buck }\end{array}$ \\
\hline $\begin{array}{l}\text { Normal } \\
\text { (animals/ha) }\end{array}$ & $(0,06)$ & $0,05: 0,28$ & $0,03: 0,14$ & $0,02: 0,19$ \\
\hline $\begin{array}{l}\text { Standardized } \\
\text { (duiker equivalents/ha) }\end{array}$ & $(0,29)$ & $: 0,28$ & $: 0,17$ & $: 0,19$ \\
\hline
\end{tabular}


Table 4

Stomach contents of blue duiker compared to the composition of freshly fallen leaves collected from forest floor

\begin{tabular}{|c|c|c|c|c|c|}
\hline & & \multicolumn{4}{|c|}{ Duiker (TCNP) } \\
\hline & & \multicolumn{3}{|c|}{ Stomach content } & \multirow{2}{*}{$\begin{array}{l}\text { Forest } \\
\text { Leaf } \\
\text { litter } \\
\text { mass }(\%)\end{array}$} \\
\hline & & $\begin{array}{l}\text { Estimated } \\
\text { numbers }\end{array}$ & $\begin{array}{l}\text { Dry } \\
\text { mass } \\
(\%)\end{array}$ & $\begin{array}{l}\% \text { of } \\
\text { identified } \\
\text { leaves }\end{array}$ & \\
\hline \multicolumn{6}{|l|}{ Fruit: } \\
\hline Dietes iridioides & (G) & 22 & $28,5^{\natural}$ & - & $6,0(\mathrm{G})$ \\
\hline Canthium mundianum & (T) & 125 & $13,3^{8}$ & - & 0,2 \\
\hline Fungi & (G) & 2 & 0,7 & - & 0,0 \\
\hline \multicolumn{6}{|l|}{ Dicotylendonous leaves: } \\
\hline Unidentified & $(\mathrm{T})$ & 580 & 50,3 & - & - \\
\hline Identified & (T) & 84 & 7,4 & & - \\
\hline \multicolumn{6}{|c|}{ Identified dicotylendonous leaves: } \\
\hline Canthium obovatum & (T) & - & 5,1 & $68,0^{8}$ & 3,7 \\
\hline Canthium mundianum & $(\mathrm{T})$ & - & 0,8 & $10,7^{8}$ & 1,1 \\
\hline Cassine papillosa & (T) & - & 0,4 & $5,3^{8}$ & 2,7 \\
\hline Apodytes dimidiata & (T) & - & 0,4 & $5,3^{8}$ & 1,7 \\
\hline Olea capensis macrocarpa & (T) & - & 0,4 & 5.3 & 9,8 \\
\hline Olinia ventosa & (T) & - & 0,3 & 4,0 & 9,3 \\
\hline Ocotea bullata & (T) & - & 0,0 & 0,0 & 0,7 \\
\hline Maytenus peduncularis & (T) & - & 0,0 & 0,0 & 0,0 \\
\hline Nuxia floribunda & (T) & - & 0,0 & 0,0 & 1,1 \\
\hline Diospyros whyteana & (T) & - & 0,1 & 1,3 & 0,6 \\
\hline Pterocelastrus tricuspidatus & (T) & - & 0,0 & 0,0 & $18,5^{\natural}$ \\
\hline Gonioma kamassi & (T) & - & 0,0 & 0,0 & $9,3^{8}$ \\
\hline Curtisia dentata & (T) & - & $<0,1$ & 0,5 & $9,8^{8}$ \\
\hline Trichocladus crinitus & (S) & - & 0,0 & 0,0 & $6,4^{8}$ \\
\hline Rapanea melanophloeos & (T) & - & 0,0 & 0,0 & $9,6^{9}$ \\
\hline Podocarpus latifolius & (T) & - & 0,0 & 0,0 & 1,7 \\
\hline Podocarpus falcatus & (T) & - & 0,0 & 0,0 & 0,6 \\
\hline Cassine eucleiformis & (T) & - & 0,0 & 0,0 & 1,2 \\
\hline
\end{tabular}

(T) $=$ tree, height $>2,5 \mathrm{~m}$

(S) $=$ shrub, height $=1,0-2,5 \mathrm{~m}$

(G) = ground flora, height $<0,5 \mathrm{~m}$

(A) = abundant

$=$ marked differences between stomach content and forest litter.

moved out of the observer's range of visibility before being detected, resulting in an underestimation of duiker numbers (Bowland 1990a). Despite this, density estimates from transect counts were similar to those from game drives (Table 1; Mann-Whitney $U$-test, $\mathrm{z}=0,44 \& 0,35 ; d f=158 \& 29 ; P$ $>0,10$ for TCNP \& TFNP respectively; Siegel 1956).

The first game drive count in the TFNP, where beaters were unfamiliar with the con- ditions, was much lower than subsequent drive counts (namely, 2 v. 5, 7, 9 duikers), as well as the largest group of duikers recorded on a transect. This count was therefore assumed to be inaccurate and excluded from the density calculations in Table 1 . In the TCNP replicate drive counts corresponded well with both each other $(\mathrm{SE}=0,58)$ and estimates from transect counts (Table 1).

Counts of faecal pellet piles, although less accurately done than drive- or transect 
Table 5

Structural characteristics and species composition of forests in the study areas of the TCPs relative to those in Umdoni Park and sections A - C of Kenneth Stainbank Nature Reserve (KSNR) (Bowland 1990a). Key:

$D B H=$ diameter at breast height, ${ }^{\circ}$ species recorded in duiker stomach

\section{Characteristics:}

Trees (> 2,5 $\mathrm{m}$ high)

Numbers measured

Size frequency (\%)

$\mathrm{DBH}>15 \mathrm{~cm}$ (A)

DBH $<15 \mathrm{~cm}$

Basal areas $\left(\mathrm{cm}^{2}\right) \mathrm{ha}^{-1}$

Stem densities

Trees $\left(\mathrm{ha}^{-1}\right)$

Shrubs $\left(\right.$ ha $\left.^{-1}\right)$

Trees /shrubs (B)

$[\%$ trees $>15 \mathrm{~cm}] /[$ trees / shrubs] or $(\mathrm{A} / \mathrm{B})$

Number of species $(n=90)$

Trees

Shrubs

Duiker densities

\begin{tabular}{llllll} 
TCNP & TFNP & Umdoni & KSNR-C & KSNR-A & KSNR-B \\
\hline 280 & 272 & 133 & 300 & 136 & 300 \\
& & & & & \\
27,8 & 24,3 & 9,8 & 4,3 & 5,9 & 2,7 \\
72,2 & 75,8 & 90,2 & 95,7 & 94,1 & 97,3 \\
285 & 408 & 226 & 128 & 133 & 82
\end{tabular}

Composition:

Dominant trees $(>2,5 \mathrm{~m}$ high)

Trichocladus crinitus

Olea capensis macrocarpa ${ }^{\gamma}$

Cassine papillosa ${ }^{\curlyvee}$

Gonioma kamassi

Pterocelastrus tricuspidatus

Podocarpus latifolius

Cassine peragua

\section{6}

3629

2892

1765

128

1993

2572

1,75

5724

1784

2941

2451

1933

15,9

1,98

0,93

1,23

0,75

Acokanthera oppositifolia

Maytenus peduncularis

Rapanea melanophloeos

12,3

$9,7 \quad 4,9$

4,8

3,6

23

$19 \quad 28$

27

28

21

7
0,19

5

17

22

0,17

3,2

22
1,6

17

16

$1,1 \quad 0,9$

Burchellia bubalina

Ocotea bullata

Nuxia floribunda

Apodytes dimidiata ${ }^{8}$

Diospyros whyteana

Rothmannia capensis

$\begin{array}{llll}\text { TCNP } & \text { TFNP } & \text { Umdoni } & \text { KSNR-C } \\ 23,2 & 40,1 & - & - \\ 7,1 & 6,6 & - & - \\ 6,4 & 1,8 & - & 3,3 \\ 6,1 & 3,7 & - & - \\ 5,4 & 1,5 & - & - \\ 5,0 & 8,8 & - & - \\ 5,0 & 0,0 & - & - \\ 4,3 & 0,0 & - & - \\ 3,9 & 0,7 & - & - \\ 3,6 & 0,0 & <3,0 & - \\ 1,8 & 4,8 & - & - \\ 1,4 & 8,8 & - & - \\ 1,4 & 2,9 & - & - \\ 1,4 & 2,9 & <3,0 & - \\ 1,1 & 2,9 & - & - \\ 0,0 & 1,8 & - & -\end{array}$

Palatable trees

Canthium obovatum ${ }^{\text {q }}$

Canthium mundianum ${ }^{\text {? }}$

$\begin{array}{ll}1,4 & 1,5 \\ 1,1 & 0,7\end{array}$

$<3,0$

$<2,8$

Dominant shrubs (1 - 2,5 m high)

Trichocladus crinitus

Carissa bispinosa

60,0

15,4

Ocotea bullata

$(1,1)$

85,7

0,0

5,1

counts, did confirm that duiker densities were extremely low in the TNPs (Table 1).

Blue duiker density assessments from various southern Cape forests ranged from 0,09 to 0,55 duikers/ha (Table 2), and were comparable to those, "metabolically" standard- ized relative to blue duiker, of bushbuck from these forests (Table 3).

In 95 percent of feeding observations $(n=19)$ blue duikers foraged at ground level and often (78 \% of the records) in areas where ground flora was scarce (cover < $10 \%)$. 


\begin{tabular}{|c|c|c|c|c|}
\hline \multirow[t]{2}{*}{ Prey } & \multicolumn{2}{|c|}{ Leopard } & \multicolumn{2}{|c|}{ Caracal } \\
\hline & $\begin{array}{l}\text { Occur- } \\
(\%)\end{array}$ & $\begin{array}{l}\text { Rel.freq. } \\
(\%)\end{array}$ & $\begin{array}{l}\text { Occur. } \\
(\%)\end{array}$ & $\begin{array}{l}\text { Rel.freq. } \\
(\%)\end{array}$ \\
\hline Birds & 27 & 20 & 29 & 21 \\
\hline Rodents & 15 & 11 & 43 & 32 \\
\hline Dassie (Procavia capensis) & 15 & 11 & 14 & 11 \\
\hline Blue duiker (Philantomba monticola) & 27 & 20 & 7 & 5 \\
\hline Bushpig (Potamochoerus porcus) & 12 & 9 & 7 & 5 \\
\hline Bushbuck (Tragelaphus scriptus) & 8 & 6 & - & - \\
\hline Baboon (Papio ursinus) & 8 & 6 & - & - \\
\hline Porcupine (Hystrix africaeaustralis) & 8 & 6 & - & \\
\hline Caracal (Felis caracal) & 4 & 3 & - & - \\
\hline Sheep & $\therefore$ & . & 7 & 5 \\
\hline Insects & 12 & 9 & 29 & 21 \\
\hline
\end{tabular}

These duikers appeared to feed primarily on freshly fallen leaves and fruit, and were very selective in their foraging, sniffing at numerous food items, but eating only a few. This was supported by the stomach analysis, where leaves and fruit from trees $(>2,5 \mathrm{~m}$ high) comprised about 71 percent (by mass) of the ingested food, and relative to food items collected from the forest floor, there appeared to be a strong selection for leaves of the trees Canthium obovatum and $C$. mundianum, as well as seed pods of the iris Dietes iridioides (Table 4).

The forests of the TNPs differ from those studied by Bowland (1990a) in Natal, with densities of both large trees (height $>2,5 \mathrm{~m}$; $\mathrm{DBH}>15 \mathrm{~cm})$ and shrubs ( $1-2 \mathrm{~m}$ high) being greater in the TNPs (Table 5). Furthermore, few tree species are common to both forest groups, and the tree ( $>2,5 \mathrm{~m}$ high) and shrub (1-2,5 $\mathrm{m}$ high) strata in the TNPs are dominated by the apparently unpalatable Trichocladus crinitus, while palatable trees Canthium obovatum and C. mundianum and the iris Dietes iridioides are uncommon (Tables 4 \& 5).

Blue duiker remains were respectively recorded in 27 and 7 percent of the leopard and caracal scats containing identifiable prey items (Table 6).

\section{Discussion}

All duiker species extensively studied have been found to be territorial (Jarman 1973; Bowland 1990a), and, contrary to Crawford's (1984) results, transect counts for the Blue Duiker Trail and study period showed no significant seasonal (summer v, winter) variation (anova $=0,81 ; d f=4 \& 152 ; P>10$ ). Likewise, mean density estimates from transect counts done during August 1987, April 1988 and August 1988 in the Kenneth Stainbank Nature Reserve (KSNR) were similar $[1,53,1,55$ and 1,44 blue duikers/ha respectively (Bowland 1990a)], suggesting that variable strip transects may be successfully employed during any season.

Blue duiker densities from the TNPs are similar to those determined from Von Gadow's (1978) and Koster \& Harts' work (1988) in four southern Cape and two Zaïrese forests respectively (Table 2). However, except for one, all these values are at least three times lower than densities recorded in the Umdoni Park \& KSNR (A - C) in Natal (Bowland 1990a, Table 2). Such discrepencies in population densities are presumably caused by factors such as predation, food or habitat or a combination of these three.

Likely predators of blue duikers in the TNPs are man, dogs, caracal and leopard 
Table 7

The frequencies of occurrence of the ten dominant tree species in the KSNR C and KSNR B, feeding preference scores of blue duiker for freshly picked and fallen leaves of these trees (modified from Bowland 1990a), as well as the estimated availability of food and blue duiker densities

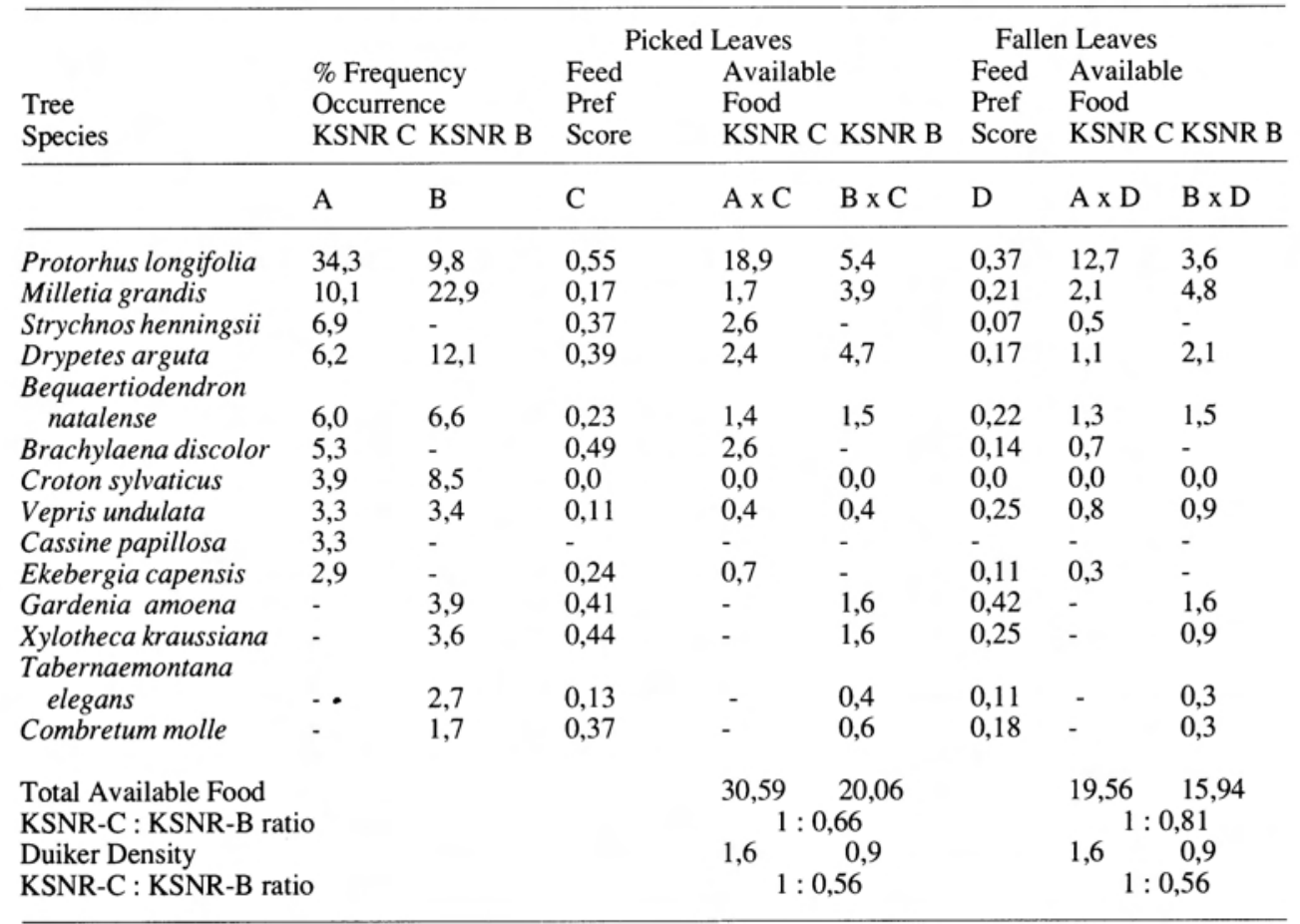

(Liversidge 1966; Robinson 1976; Smithers 1983; Crawford \& Robinson 1984). However, since the late 1970 s the study areas have been regularly patrolled by park officials, and during this survey no signs of poachers, snares or dogs were seen. Furthermore, although blue duiker remains were recorded in 27 percent of the leopard scats analysed (Table 6), numbers of leopard in the TNPs appear low, because despite effective coverage during the two year study period, only 26 leopard scat piles were found. Therefore, factors other than predation are probably responsible for the low blue duiker densities in the Tsitsikamma national parks.

Blue duikers are territorial, obligate forest dwellers, and its forest habitat must provide both food and shelter throughout the year (Bowland 1990a). The tree stratum $(>2,5 \mathrm{~m}$ high) is the primary food source for blue duikers, while the shrub layer ( $1-2,5 \mathrm{~m}$ high) is important in terms of cover (pers. obs.; Bowland 1990a). Above a certain threshold level of stem densities, Bowland (1990a) recorded a positive affiliation between blue duiker densities and the quotient from percentage occurrence of big trees (DBH $>15$ $\mathrm{cm}$ ) divided by the proportion of shrub to tree densities in the study sites (A / B in Table 5). The results of this study failed to conform with Bowland's (1990a) values, because despite the higher quotients recorded in the TNPs, duiker densities were lower than in Natal (Table 5). This discrepancy might be due the fact that the shrub and tree densities measurements failed to quantify the growth form of the plants, which would affect the plants ability to provide shelter or food for duikers. For example, the slender, erect stem and leafy branches of witch-hazel Trichocladus crinitus, which dominates the southern Cape forests (Table 5; Von Breitenbach 1974), provides scant cover for 
duikers compared to a sprawling, multistemmed shrub, such as Carissa bispinosa.

The density of shrubs in the TFNP was 1,6 times greater than in the TCNP. Despite this, blue duiker density estimates from both transects and game drives in these two areas were similar (Mann-Whitney $U$-test, $\mathrm{z}=0.38 \&$ $-0,44 ; d f=182,4 ; P>0,10)$ ); as were faecal pellet counts from forests (ca. $80 \mathrm{~km}$ west of TFNP) with abundant- and fairly abundant undergrowth cover (Von Gadow 1978). This suggested that shrub densities generally do not significantly influence the duiker densities in the southern Cape forests.

Small ruminants have high metabolic requirements relative to their stomach capacities (Schmidt-Nielsen 1985) and are under pressure to feed selectively (Milton 1979; McNaughton 1987). Bowland (1990a) recorded a positive correlation between feeding preferences of blue duikers and condensed tannin concentrations of freshly picked leaves. Although contrary to recorded trends in other "herbivores" [namely a preference for plants poor in condensed tannins (Oates et al. 1977; McKey et al. 1981; Cooper et al. 1988 )], the results, together with field observations, indicate that blue duikers are very selective foragers.

Dicotyledonous leaves are the single most important dietary component of blue duikers in the Natal forests (Bowland 1990a), and constituted approximately 57 percent of the stomach contents analysed in this study (Table 4). Nevertheless, Bowland (1990a) recorded a strong, negative correlation $(r=0,89, P>0,05)$ between fruit (a scarce, unreliable food source in dry coastal forests) and freshly fallen leaves (an abundant, yearround food source), suggesting a much greater preference for fruit. In the TNPs less than 45 percent of the dominant trees (frequency of occurrence $>1,7 \%$ in Table 5) fruit successfully every year. For example, although Pterocelastrus tricuspidatus, Cassine papillosa, C. peragua and Canthium obovatum flower annually, they only develop full fruit crops every second or third year, while Podocarpus latifolius, Rapanea melanophloeos, Apodytes dimidiata, Olea capensis subsp. macrocarpa, Nuxia floribunda and Gonioma kamassi, have flowering intervals of two or more years (Phillips 1926; Von Breitenbach 1974). Furthermore, the dominant "annually" fruiting species, Trichocladus crinitus, has small, encapsulated fruit (Von Breitenbach 1974), which are apparently seldom foraged on by birds or animals (pers. obs.). Therefore, fruit is a scarce, unreliable food source in the Tsitsikamma national parks.

The potential of freshly fallen leaves to serve as a prolific, year-round food source may also be limited, as the vegetation of the FNPs is dominated by the apparently unpalatable Trichocladus crinitus, Pterocelastrus tricuspidatus, Gonioma kamassi and Rapanea melanophloeos, while palatable trees, Canthium obovatum and $C$. mundianum, are scarce (Table $4 \& 5$ ). Furthermore, the natural vegetation of the southern Cape is often deficient in copper (Joubert et al. 1969 in Odendaal 1983; Koen 1984), and the mean copper concentration determined from foliar analysis of three indigenous tree species from this region was $8 \mathrm{ppm}$ (Koen 1988), lower than the minimum recommended for sheep on natural pastures in this region (Koen 1988). The liver copper concentration of $59 \mathrm{ppm}$ determined from the blue duiker analysed was less than the means (137 ppm; range 29 -533 ppm) from bushbuck in the Knysna forests (Odendaal 1983) and (84 ppm; range 18 - $208 \mathrm{ppm}$ ) from bontebok (Damaliscus dorcas dorcas) suffering from copper deficiencies (Zumpt \& Heine 1978), but similar to sheep in winter from the nearby George area $(\bar{x}=50 \mathrm{ppm})$, where pastures are known to be deficient in copper (Odendaal 1983). Despite the low copper concentration in its liver, the blue duiker analysed showed no obvious symptoms of a copper deficiency (Maynard \& Loosli 1969), being large (4,9 kg), with strong bones, glossy coat and lactating mammary glands. Nevertheless, the low mineral content and palatability of the vegetation in the southern Cape forests (Odendaal 1983; Koen 1984; Koen et al. 1988; Table 4), may increase the need of blue duikers to forage 
selectively. McKey et al. (1978) postulated that as a consequence of similar feeding pressures, the monkey Colobus satanas in the Douala-Edea forest exists at a density roughly one-tenth the combined density of the two colobus species in the nutrient richer Kibale forest. It is, therefore, interesting to note that the densities of bushbuck in the nutrient poor southern Cape forests are approximately one-quarter those recorded from the savanna biome (Odendaal \& Bigalke 1979; Seydack 1983; Van Daalen 1984), and that the blue duiker density in the KSNR (A) is approximately half that in the $\operatorname{KSNR}(\mathrm{C})$, where the estimated availability of palatable leaves was 1,3 times greater (Table 7). Hence diet quality may be regulating the population densities (Milton 1982; Crawley 1983; Waterman et al. 1988 in Bowland 1990a).

Bushbuck and blue duiker are the major antelope species in the Knysna forests (Von Breitenbach 1974; Robinson 1976; Seydack 1983), both feeding primarily on indigenous tree foliage (Odendaal 1983; Table 4). Therefore, if palatable foliage is limiting in the southern Cape forests, then these two species, of different sizes (ca. $35 \mathrm{~kg}$ v. $4,2 \mathrm{~kg}$, Smithers 1983) and subject to different predation pressures (Table 6), could be expected to have low and comparable "metabolically" standardized, population densities. This is indeed the situation (Table 3), and the above, together with the fact that Koster \& Hart (1988) determined no significant difference between the densities of blue duiker from two forests having markedly different histories of hunting and snaring $(t=0,90 ; d f=13$ (drives); $t=1,53 ; d f=28$ (pellet counts) $P>0,05$ ), suggests that habitat rather than predation is the major factor controlling the population densities in the Tsitsikamma national parks.

Changes in habitat may also have been responsible for the decline in blue duiker abundance in the southern Cape during the late 1940s (Crawford \& Robinson 1984). The annual rainfall values recorded at Bloukransbos in the Tsitsikamma for 1945 , 1946 and 1949 were the lowest over the 90 year period 1890 - 1979 (Crawford \& Robin- son 1984), and the ensuing drought would have adversely affected the undergrowth cover, as well as leaf and fruit production in these forests. This in turn would have reduced the duikers' ability to escape predation, grow and raise offspring. The recovery of these populations was slow, but numbers have increased (Crawford \& Robinson 1984). Transect counts (per kilometre) along the western sector of the Blue Duiker Trail (Table 1) are similar to those recorded by Crawford (1984; unpubl. data) along the eastern sector of the trail during 1980-2 $(t=0,922 ; d f=515 ; P$ $>0,10$ ), suggesting that the population is near its upper asymptote and that further increases in population densities are unlikely.

\section{Acknowledgements}

We thank Dr. A. E. Bowland (University of Natal), for his suggestions and constructive criticism, as well as Messrs. M. Masiyandima (Natural History Museum, Bulawayo) and B. Wilson for scat analyses. Financial support by the National Parks Board, encouragement by Dr. A. Hall-Martin and the assistance of Messrs. L. Watson (Saasveld) and D. Bower, K. Klaaste, R. Kivetts, P. Scott (TCNP staff members) is gratefully acknowledged.

\section{References:}

BOURQUIN, O., J. VINCENT and P.M. HITCHINS. 1971. The vertebrates of the Hluhluwe Game Reserve-Corridor (state land)Umfolozi Game Reserve complex. Lammergeyer 14: 1-119.

BOWLAND, A.E. 1990a. The ecology and conservation of blue duiker and red duiker in Natal. Ph.D. thesis, University of Natal, Pietermaritzburg, RSA.

BOWLAND, A.E. 1990b. The response of red duikers Cephalophus natalensis to drive counts. Koedoe 33 (1): 47-53.

COLLINSON, R. H. 1985. Selecting wildlife census techniques. Institute of Natural Resources, Monograph 6. Pietermaritzburg: University of Natal Press.

COOPER, S.M., N. OWEN-SMITH and J.P. BRYANT. 1988. Foliage acceptability to browsing ruminants in relation to seasonal changes in leaf chemistry of woody plants in a South African savanna. Oecologia (Berlin) $75: 336-342$.

CRAWFORD, R.J.M. 1984. Activity, group structure and lambing of blue duikers Cephalophus monticola in the Tsitsikamma National Parks, South Africa. South African Journal of Wildlife Research 14 (3): 65-68.

CRAWFORD, R.(J.M.) 1985. Saving Tsitsikamma's blue duikers. Custos 13 (11): 11 -12. 
CRAWFORD, R.J.M. and G.A. ROBINSON. 1984. History of the blue duiker Cephalophusmonticola population in the Tsitsikamma forests, Republic of South Africa. Koedoe 27: 61-71.

CRAWLEY, M.J. 1983. Herbivory: The Dynamics of Animal-plant Interactions. London: Blackwell Scientific Publications.

GELDENHUYS, C.J. 1981. Notes on the Tsitsikamma Forest National Park. Report for National Parks Board by Saasveld Forestry Research Station.

GROBLER, J.H. and V.J. WILSON. 1972. Food of the leopard Panthera pardus (Linn.) in the Rhodes Matopos National Park, Rhodesia, as determined by faecal analyses. Arnoldia (Rhod) 5 (35): $1-9$.

HANEKOM, N., A. SOUTHWOOD, and M. FERGUSON. 1989. A vegetation survey of the Tsitsikamma Coastal National Park. Koedoe 32 (1): $47-67$.

JARMAN, J.P. 1973. The social organisation of antelope in relation to their ecology. Behaviour 48: $215-267$

JOUBERT, J.G.V., H.W. STINDT and I.S. PEROLD. 1969. The nutritive value of natural pastures in the district of Calitzdorp, George, Knysna, Mossel Bay, Oudtshoorn and Uniondale in the winter rainfall area of the Republic of South Africa.Technical Communication No 82, Department of Agriculture and Technical Services.

KOEN, J.H. 1984. A study of the distribution, population composition, movement and feeding of the Knysna elephants Loxodonta africana africana (Blumenbach 1797). Unpublished report. S84/6. Department Environment Affairs.

KOEN, J.H. 1988. Trace elements and some other nutrients in the diet of the Knysna elephant. South African Journal of Wildlife Research 18 (3): 109 -110 .

KOEN, J.H., A.J. HALL-MARTIN and T. ERASMUS. 1988. Macro nutrients in plants available to the Knysna, Addo and Kruger National Park Elephants. South African Journal of Wildlife Research $18(2): 69-71$.

KOSTER, S.H. and J.A. HART. 1988. Methods of estimating ungulate populations in tropical forests. African Journal of Ecology 26: 117 -126.

LIVERSIDGE, R. 1966. The blue duiker or bloubokkie. Eastern Cape Naturalist 28:8-10.

MCKEY, D., P.G. WATERMAN, C.N. MBI, J.S. GARTLAND and T.T. STRUHSAKER. 1978. Phenolic content of vegetation in two African rain forests: ecological implications. Science 202: 6164.

MCKEY, D.B., J.S. GARTLAND, P.G. WATERMAN and G.M. CHOO. 1981. Food selection by black colobus monkeys in relation to plant chemistry. Biological Journal of the Linnean Society 16: $115-146$.

MAYNARD, L.A. and J. K. LOOSLI. 1969. Animal nutrition. London: McGraw-Hill.

MCNAUGHTON, S.J. 1987. Adaptation of herbivores to seasonal changes in nutrient supply. In: HACKER, J.B. and J.H. TERNOUTH, (eds.).
The Nutrition of Herbivores. London: Academic Press.

MILTON, K. 1979. Factors influencing leaf choice by the howler monkey : a test of some hypotheses of food selection by generalist herbivores. American Naturalist 114: 362 -378.

MILTON, K. 1982. Dietary quality and demographic regulation in a howler monkey population. In: LEIGH, G.E., A.R. RAND and D.M. WINDSOR (eds.). The Ecology of a Topical Forest: Seasonal Rhythms and Long-term Changes. Washington: Smithsonian Institution Press.

MUELLER-DOMBOIS, D. and H. ELLENBERG. 1974. The Aims and Methods of Vegetation Ecology. London: Wiley.

NORTON, P.M., A.B. LAWSON, S.R. HENLEY and G. AVERY. 1986. Prey of leopards in four mountainous areas of the southern Cape Province. South African Journal of Wildlife Research 16: $47-52$.

OATES, J.F., T. SWAIN and J. ZANTOVSKA. 1977. Secondary compounds and food selection by colobus monkeys. Biochemical Systematics and Ecology 5: 317 - 321.

ODENDAAL, P.B. 1983. Feeding habits and nutrition of bushbuck in the Knysna forests during winter. South African Journal of Wildlife Research 13: 27 -31.

ODENDAAL, P.B. and R.C. BIGALKE. 1979. Home range and groupings of bushbuck in the southern Cape. South African Journal of Wildlife Research 9 (3 \& 4): 96 -101.

ODENDAAL, P.B., M.J.CAMERON, and A.J. PRIDAY. 1980. An evaluation of bushbuck track counts in the Knysna forests. South African Forestry Journal 113: 65 - 68.

PHILLIPS, J.F.V. 1926. General biology of the flowers, fruits, and young regeneration of the more important species of the Knysna forest. South African Journal of Science 23: 366 -417.

ROBINSON, G.A. 1976. Notes on mammals encountered in the Tsitsikamma National Parks. Koedoe 19: $145-152$.

SCHMIDT-NIELSEN, K. 1985. Animal Physiology: Adaptation and Environment. Cambridge: Cambridge University Press.

SEYDACK, A.H.W. 1983. Application of a photorecording device in the census of larger rain-forest mammals. South African Journal of Wildlife Research. 14 (1): 10-14.

SIEGEL, S. 1956. Nonparametric Statistics for the Behavioural Sciences. Tokyo: McGraw-Hill Kogakusha.

SKEAD, C.J. 1980. Historical Mammal Incidence in the Cape Province. Volume 1. The Western and Northern Cape. Cape Town: Department of Nature and Environmental Conservation of the Provincial Administration of the Cape of Good Hope.

SMITHERS, R.H.N. 1983. The Mammals of the Southern African Subregion. Pretoria: University of Pretoria.

SMITHERS, R.H.N. 1986. South African red data book - terrestrial mammals. South African Na- 
tional Programmes Report No. 125. CSIR, Pretoria.

SNEDECOR, W.R. 1965. Statistical Methods. Iowa State University Press.

THESEN, H.P, 1959 . Wildlife in the Knysna district. Eastern Cape Naturalist 8: 10-12

VAN DAALEN, J.C. 1984. Distinguishing features of forest species on nutrient-poor soils in the Southern Cape. Bothalia 15 (1 \& 2): 229 -239.

VON BREITENBACH, F. 1974. Southern Cape forests and trees. Pretoria: Government Printers.

VON GADOW. K. 1978. A pellet count of blue duiker and bushbuck in the Knysna Forests. South African Forestry Journal 107: 77-81.

WATERMAN, P.G..J.A.M. ROSS, E.L. BENNETT and A.G. DAVIES. 1988. A comparison of floris- tics and leaf chemistry of the tree flora in two Malaysian rain forests and the influence of leaf chemistry on populations of colobine monkeys in the Old World, Biological Journal of the Linnean society 43: 1 - 32 .

WALKER, C. 1981. Signs of the wild. Johannesburg: Everton Book Press.

WILSON, V.J. 1987. Action plan for duiker conservation. IUCN/SSC Antelope Specialist Group and Chipangali Wildlife Trust. Chipangali, Bulawayo, Zimbabwe.

ZUMPT, I.F. and E.W.P. HEINE. 1978. Some veterinary aspects of bontebok in the Cape of Hope Nature Reserve. South African Journal of Wildlife Research 8: $131-134$ 